\title{
Ibrah Based on Malay Food Culture in The Selected Malay Short Stories
}

Kamariah Kamarudin, Pabiyah Toklubok@Hajimaming, Zaitul Azma Zainon Hamzah, Haliza Abdul Rahman

To Link this Article: http://dx.doi.org/10.6007/IJARBSS/v11-i19/12088

DOI:10.6007/IJARBSS/v11-i19/12088

Received: 11 August 2021, Revised: 31 August 2021, Accepted: 23 September 2021

Published Online: 19 October 2021

In-Text Citation: (Kamarudin et al., 2021)

To Cite this Article: Kamarudin, K., Toklubok@Hajimaming, P., Hamzah, Z. A. Z., \& Rahman, H. A. (2021). Ibrah Based on Malay Food Culture in The Selected Malay Short Stories. International Journal of Academic Research in Business and Social Sciences, 11(19), 484-495.

Copyright: (c) 2021 The Author(s)

Published by Human Resource Management Academic Research Society (www.hrmars.com)

This article is published under the Creative Commons Attribution (CC BY 4.0) license. Anyone may reproduce, distribute, translate and create derivative works of this article (for both commercial and non-commercial purposes), subject to full attribution to the original publication and authors. The full terms of this license may be seen

at: http://creativecommons.org/licences/by/4.0/legalcode

Special Issue Title: Youth and Community Wellness, 2021, Pg. 484 - 495

Full Terms \& Conditions of access and use can be found at http://hrmars.com/index.php/pages/detail/publication-ethics 


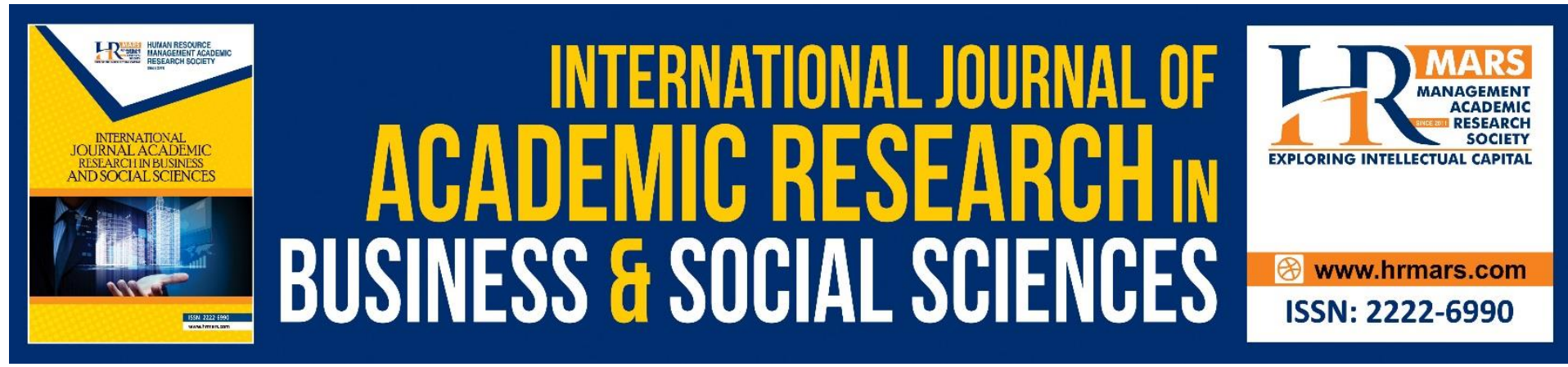

\title{
Ibrah Based on Malay Food Culture in The Selected Malay Short Stories
}

\section{Kamariah Kamarudin ${ }^{1,2}$, Pabiyah Toklubok@Hajimaming ${ }^{1,2}$,} Zaitul Azma Zainon Hamzah ${ }^{1,2}$, Haliza Abdul Rahman ${ }^{1,3}$

${ }^{1}$ Institute for Social Science Studies, Putra Infoport, Universiti Putra Malaysia, 43400 Serdang, Selangor, Malaysia, ${ }^{2}$ Department of Malay Language, Faculty of Modern Language and Communication, Universiti Putra Malaysia, 43400 Serdang, Selangor, Malaysia, ${ }^{3}$ Faculty of Medicine, Universiti Putra Malaysia, 43400 Serdang, Selangor, Malaysia.

Corresponding Author Email: kkamaria@upm.edu.my

\begin{abstract}
The development of Malay literature has shown the close relationship between the society in producing works. This is because of the author's sensitivity to current issues and the environment in the society that can be used as ibrah for the readers. It is found that the question posed in literary works particularly in prose works, whether it is a novel or a short story, begins from the author's ability to convey a beneficial message in the work. From the perspective of Islam, ibrah is a teaching that can be apply as a lesson in life. Therefore, this paper will explore the ibrah based on the Malay food culture in the chosen Malay short stories, namely Bihun Goreng Berkuah Laksa, Serondeng Nasi Pulut dan Kerana Kuih Koci. The study will be observing the symbolism in Malay food in order to be aligned with the (Malay) community which is full of diversity in food and dishes. This research is a qualitative study that uses the method of textual analysis. Based on the study, it is clearly shown that through the Malay food culture, ibrah can be the guide and lesson in the struggle of life. This is because the symbolism in Malay food culture managed to educate people towards goodness, truth and beauty. Hence, this will also build the personality in unraveling the benefits that surround society today.
\end{abstract}

Keywords: Ibrah, Culture, Malay Food, Malay Short Stories, Selection, Recent

\section{Introduction}

In the context of the development of the local Malay literature, the relationship between the work, the author and the audience is that they mutually need each other. Literary works like prose or poems are very much needed as it is beneficial for the readers to acquire as many lessons as possible. Based on the work presented by the author, it has shown various issues raised which have led to a message in the work. Hence, lesson or ibrah in the context of Islam is necessary in a work produced by an author as wasilah (nearness) in life. This is in line with surah al-Hasyr verse 2 as translated: "So take a lesson (from this), O people of insight!" Based on the translation of the verse, it is clear that ibrah can be used as a support for the readers in obtaining a useful message in producing work. Moreover, Malay community is full of 
diverse cultures that can portray the picture of the lives of those involved. One of those is the food culture that highlights the relationship between the Malay community and the circles. Generally, Malay food culture that is found in Malaysia shows a multi-racial population, led by a variety of traditional food for generations. It was observed that Malay food culture inherited in this community is very unique because it also shows the demographic placement of each region. This can be traced through the various cuisines found in the homeland that are served in a society. Masak asam dishes for instance, is an example of Malay food culture that comes from the state of Malacca. Followed by Rendang Tok (Perak), Ikan Singgang (Terengganu), Gulai Lemak Cili Api (Negeri Sembilan), Laksa Penang (Penang Island) Gulai Tempoyak Ikan Patin (Pahang), Nasi Kerabu (Kelantan), and others that captured Malay food culture are rich with the ingredients and dishes that are flavourful.

Therefore, based on Malay food cultures found in the society has led to the homeland author's effort to capture the issue in the Malay literary works. Thus, this study will explore the development of Malay food culture in the modern Malay literary works. It was found that the author raised the issue of Malay food culture as the representative of the demographic and the background of their authorship.

\section{Research Objective}

The objective of this research is to study ibrah, which refers to lessons that are found through Malay food culture dishes. Therefore, three short stories, namely Kerana Kuih Koci (Fathul Khair, 2016), Bihun Goreng Berkuah Laksa (Nordin, 2015) and Serondeng Nasi Pulut (Jamilah, 2016) was adapted as the instruments of the study. In addition, this study will also analyze the three short stories based on ibrah according to the Islamic perspective on two classifications, namely ibrah in religion and ibrah on family as an element of teaching to the readers.

\section{Research Methodology}

This study is a qualitative study which uses a text analysis method. A total of three short stories were selected as the data of this study. These three short stories were analysed based on the views from the scholars in the study of culture, literature and religion.

\section{Research Data}

This study analysed three short stories, namely Kerana Kuih Koci, Bihun Goreng Berkuah Laksa and Serondeng Nasi Pulut. The short story Kerana Kuih Koci was found in Kumpulan Cerpen Remaja Sfera Bersegi 5 (Khair, 2016), Bihun Goreng Berkuah Laksa was found in Kumpulan Cerpen Bihun Goreng Berkuah Laksa (Nordin, 2015) and Serondeng Nasi Pulut was found in Kumpulan Cerpen Remaja Serondeng Nasi Pulut (Jamilah, 2016). All these three short stories were published by the Malaysian Institute of Translation \& Books.

\section{Malay Food Culture in Modern Malay Literary Work}

Although the promotion of Malay food culture has been presented by the author in several homeland Malay literary works since the 1980s, the outcome, however, is relatively rare. Only a few short stories are found that make Malay menus and dishes either in short stories or novels. Among those, some that is identified are short stories such Nasinya Tumpah (Fatimah Busu, 1980), Tulang Pekasam Ikan Puyu (Azizi, 1983), Ambuyat (Shuhaibun, 2002), Lemang Nan Sebatang (Nisah, 2009), Jeruk Maman Emak (Chih, 2011), Gulai Tempoyak Ikan Sebarau (Malim, 2013), Cinta Gendang Kasturi (Faisal, 2015). Recently, few short stories appeared, for 
instance Pulut Serunding Buat Nazihah (Shahkang, 2018), Setalam Halwa Maskat (Shahkang, 2018), Sesar Unjur Kampung Belawai (Amaruszati, 2018), and Penggemar Karipap dan Momentum Hari Lahir (Ariff, 2018). In addition, in the novel genre, among those that can be highlighted are Ketupat Cinta (Faisal, 2010) Gulai Siput Daun Kaduk (Fida, 2016), and others that make Malay food as a central pillar in producing works.

Thus, this study will explore three latest Malay short stories, namely Bihun Goreng Kuah Laksa, Serondeng Nasi Pulut and Kerana Kuih Koci. The observation on these latest Malay short stories will be aligned with ibrah in the context of Islam, namely lesson and teaching that can be adapted as message in life. Hence, lessons that can be used as a guide especially among the younger generations audience will be observed based on these three short stories which present the Malay food culture in the respective works. This is also clearly shown in the study about the importance of "mom's cooking" in Malay food culture according to the perspective of Islam which describes the elements of teachings that can be adapted as a lesson to the readers (Kamariah \& Pabiyah, 2021).

Thus, this study will explore ibrah according to the perspective of Islam as a platform of discussion and wasilah between Malay literary works specifically in the latest short stories selected.

\section{Ibrah from the Perspective of Islam}

From the perspective of Islam, ibrah is a teaching that can be apply as teaching and lesson in life. This is in line with surah al-Hasyr, verse 2 as translated: "So take a lesson (from this), 0 people of insight!" as an initiative to encourage people to often reflect themselves throughout the struggles in life. Based on the translation of the verse, it is clear that ibrah can be used as a support for the readers in obtaining a useful message in producing work. This is in line with the Islamic view that there must be some responsibilities to carry as a human being, namely as the executor of the promise with God, as the caliph of God on earth and as the developer of the amanat (trust). In this context, the creative author is responsible for bearing his trust as a caliph on earth in delivering something that can benefit the readers. The work done by the author is not just to bring an issue and the question for storytelling and having fun alone, but also to present a useful message to the readers.

In fact, in the Qur'an, there are many surahs that mention ibrah as a booster of spirit for people to keep on living. This can be observed in numbers of studies on the comprehensiveness of Islam, for instance in dealing with moral values in the Qur'an. Apart from that, ibrah is also often associated with mau'izah, which refers to reminder, however in the context of this study, the explanation will be prioritized only on teaching and lesson. In fact, the Qur'an clearly shows that the surahs in the Qur'an can be used as useful lessons and messages for human beings to keep on living life. This is in line with the views of Sheikh Dr. Fadhl Hassan Abbas, namely: "Indeed, the stories of the Qur'an are the shady trees whose fruits are very easy to pluck, having a lot of branches, never ceasing to shade those who wish to take shelter under it. Indeed, the shade of the tree of the stories of the Al-Quran always remains wide in its shade, the always non-stop flowing water under the tree, the fruits are a lot and never short of its amount and are not forbidden to anyone. So know that the miracle of the tree of the stories of the Qur'an will not cease and this tree has never been stingy from continuing to benefit human beings even though those who want to take shelter under it have various desires when approaching it. "

Based on this expression, it is clear that there are many stories in the Qur'an that can be used as ibrah, which refers to a lesson for the sake of the prosperity of human life. Thus, in the 
context of producing works of Malay literature, authors must make this an outburst of enthusiasm and motivation to write based on the guide of the Quran which constantly convey reminders for humans.

Therefore, this paper will explore the ibrah based on the Malay food culture in the chosen Malay short stories. Those short stories are Bihun Goreng Berkuah Laksa (Nordin, 2015), Serondeng Nasi Pulut (Jamilah, 2016) and Kerana Kuih Koci (Khair, 2016). Ibrah will be observed through two elements namely, ibrah about religion and ibrah about family. Generally, ibrah will be observed through the efforts of the author in raising issues and questions regarding Malay food culture that is the backbone producing work of the authors to be attributed to religion and family. It was found that the works produced by the authors represented the demographics and background of their work based on what is understood through their origins. Nordin Saad, for instance, is from the north region, hence it is not surprising that the short story produced is Bihun Goreng Berkuah Laksa which is synonymous with the northerners, followed by Jamilah Epin who was born in Simunjan, Sarawak who presented the short story Serondeng Nasi Pulut in line with the culture of the Land of the Hornbills and Fathul Khair Mohd Dahlan who is a native of Selangor presented the short story Kerana Kuih Koci in line with the menu of his community in producing their works.

\section{Ibrah Based on Malay Food Culture in Selected Short Stories}

\section{(a) Ibrah about Religion}

Ibrah about religion is a lesson learned from reading that can lead to goodness. This is in line with Surah an-Nahl verse 125 which highlights the importance of wisdom and advice on good lessons in life as translated: "Invite to the way of your Lord with wisdom and good instruction, and argue with them in a way that is best. Indeed, your Lord is most knowing of who has strayed from His way, and He is most knowing of who is [rightly] guided."

Ibrah on religion in the short story can be observed through the author's efforts to deliver useful lessons to the readers as a lesson in enhancing Islamic knowledge. Author has made Malay food turn as a lesson to guide the readers towards a life that is a life based on good values. This can be observed in all the three short stories used in the study. The preparation of Malay food in the respective short stories have brought a pure symbolism which offered ibrah on the importance of religion to the readers.

In accordance to that, based on the short story Bihun Goreng Berkuah Laksa, the use of ibrah on religion is evident in the education in a household. It shows the importance of the value of religious education that should be nurtured by a husband and wife to their children with good and halal nutrition. Hence, in the short story Bihun Goreng Berkuah Laksa, a portrayal of the character Nordiana Humairah who is the only child of Hamizah and her husband, Razali has conveyed a religious ibrah to the readers. This is because the religious education given by a mother to her child from her sincere cooking has formed a noble personality towards her daughter even though her mother has passed away. The personality of Nordiana Humairah as a girl who often remembers her mother's advice in respecting others, especially her own father is clearly displayed in this short story. Author reveals that the dish fried rice noodles with laksa gravy is a Malay food culture that can foster the sense of love and affection of a child to both parents even if the child has grown up as a teenager or adult. In fact, the fried rice noodles with laksa gravy dish is a sign of respect and to always remind each other between a child and both the parents. This is in line with the Islamic view which recommends that children should be given good and halal food as translated in Surah al-Baqarah verse 172: "O you who have believed, eat from the good [i.e., lawful] things which We have provided for 
you." Hence, the short story Bihun Goreng Berkuah Laksa has sent a religious ibrah that brings the readers to love the teachings and education of mothers perfectly through halal and nutritious food:

Nordiana Humairah watched her father lovingly. The fried rice with laksa gravy he enjoyed was carefully rejected. His eyes remained fixed on the face of Razali who was sitting in front of him. That is indeed his attitude. Nordiana Humairah has great respect for her father. Every word of her father will be heard carefully. Never at all did she turn her back on her father or look the other way when talking to her father. That was her mother's advice that was impossible to forget. She remembers the advice very well, even though her mother has passed away for almost three years. And her mother's advice is still intact in her mind as strong as Nordiana Humairah's thoughts of her mother.

(Nordin, 2015: 2)

Nordiana Humairah memerhati papanya dengan penuh kasihsayang. Bihun goreng berkuah laksa yang sedang dinikmatinya itu ditolak ke tepi dengan cermat. Matanya tetap dihalakan ke wajah Razali yang duduk di hadapannya itu. Sememangnya begitu sikapnya. Nordiana Humairah amat menghormati papanya. Setiap tutur kata papanya akan didengari penuh teliti. Tidak pernah sama sekali dia membelakangi papanya atau menoleh ke arah lain tatkala bercakap dengan papanya. Itulah pesanan mamanya yang tidak mungkin dilupai. Dia masih ingat sangat pesanan itu, walaupun mamanya sudah hampir tiga tahun pulang ke rahmatullah. Dan pesanan arwah mamanya masih terus utuh dalam fikirannya seperti teguhnya ingatan Nordiana Humairah kepada mamanya itu.

(Nordin, 2015: 2)

Next in the short story Serondeng Nasi Pulut, ibrah on religion was also presented by the author through an initiative to highlight the dish serondeng (meat floss) with glutinous rice as a useful wasilah to the readers to understand the differences between culture and religious demands. This short story expresses the point of view of a child who tries to advise his mother in religion through a serondeng with glutinous rice dish in the indigenous culture of Sarawak. It was found that this menu of Sarawak's indigenous heritage became the main dish as an intermediary between the living and the dead. This is contrary to the teachings of Islam that there is no element of worshipping of the ancestors who have died. Thus, the author shows some issues concerning the Malay community in Sarawak who are still tied to the culture that is contrary to the religion in the short story Serondeng Nasi Pulut. This short story brings out the ibrah about religion to the readers because of the serondeng with glutinous rice dish in Malay culture that should not be arbitrary. The author awakens a mother who is too fanatical to her ancestors by making the serondeng with glutinous rice dish as food to people who have died as shirk (polytheism) in religion. This can be observed in this example passage: "Yes, I 
understand. Thankfully, your sister is the one who guided me and our family to believe in The One and Only God and explained a lot of religious knowledge to us (Jamilah, 2016: 44).

In fact, the serondeng with glutinous rice dish is actually of the belief of the Malay community of the Land of the Hornbills about the difference between culture and religion demands that are often misinterpreted by most people. Hence, this story has apply the ibrah on religion that Islam is against shirk in Malay culture especially welcome in the preparation of Malay dish, serondeng with glutinous rice which is famous among the people of Sarawak. The author encourages the reader to be aware of the importance of religion knowledge as an enlightenment in life through Malay food culture:

"Yes, mom. I (Din) did the work. According to Along at that time, serving food to people who are gone, is shirk. We believe that the spirits of the dead will come to visit to eat the food served. On the other hand not a single spirit does that, mom. Along's advice at that time, prayers and alms for the dead were food for them. Not with a ritual like that, "I said at length.

(Jamilah, 2016: 45)

\begin{abstract}
"Ya, mak. Din yang buat kerja tu. Menurut Along ketika itu, menghidangkan makanan kepada orang yang sudah tiada, hukumnya syirik. Kita mempercayai bahawa roh orang yang mati akan datang bertandang untuk makan makanan yang dihidangkan. Sebaliknya tiada satu roh pun yang berbuat demikian, mak. Nasihat Along ketika itu, doa dan sedekah buat arwah itulah makanan untuk mereka. Bukannya ritual seperti itu...," ucapku panjang lebar.
\end{abstract}

(Jamilah, 2016: 45)

Next, through the short story Kerana Kuih Koci, the author presents ibrah about religion based on a child's obedience towards his mother in realizing this life. The author expresses the struggles of a mother in fulfilling her responsibilities as a woman who abides by religious orders. This short story reveals the noble heart of a mother who is able to provide the best food for her children. One of the dishes prepared by the mother is kuih koci which shows her perseverance to make her children and family happy. It was found that the preparation of the kuih koci in Malay culture is rather complex as it is necessary to complete the ingredients, such as flour, coconut filling and banana leaf core, but it's not an obstacle for a mother who is aware of the responsibility that she bears on her shoulders. The author presents the personality of a mother who is very patient, resilient and polite in raising children by providing the best and nutritious food dishes such as the making of kuih koci. The traditional cake dish presented in this short story shows the hard work of a mother who not only makes sure that her children have enough food but also the way the meal is prepared followed by salawat and prayers has brought ibrah about religion. It was found that the children in this short story were very appreciative of their mother who always prepared the best meals for the family with a load of love and attention. This can be observed as an example of the following passage: 
Indeed, mom's cooking has thousands of wisdoms.

Every touch is followed by the best salawat and prayers for her children, in order to become pious human beings and useful to all members of society. As long as the food is digested in the body, the mother's prayer will keep flowing into the tangled blood vessels.

(Khair, 2016: 9)

Sesungguhnya, air tangan daripada ibu mempunyai seribu satu hikmah. Setiap gaulan, dan sentuhan, disusuli selawat dan doa yang terbaik untuk anak-anaknya, agar menjadi insan yang soleh dan solehah serta berguna kepada sekalian marga masyarakat. Selama makanan itu terhadam di dalam jasad, selama itulah iringan doa ibu itu mengalir ke dalam pembuluh darah yang berselirat.

(Khair, 2016: 9)

\section{(b) Ibrah on Family}

Ibrah on family presents a harmonious relationship in a bond between family members. This is as stated in the Qur'an that suggests the importance of living based on love in a family as the translation of Surah Rum Verse 21: "And of His signs is that He created for you from yourselves mates that you may find tranquillity in them; and He placed between you affection and mercy. Indeed in that are signs for a people who thought."

The Ibrah about family in the short stories present lessons through dishes in the Malay food culture as a symbol of harmony in life. Thus, in the three short stories studied, this was clearly presented by the authors. Nordin Saad who used the dish fried rice noodles with laksa gravy clearly showed his attachment as a northern-born child followed by Jamilah Epin who is familiar with the background of life as a citizen of the Land of the Hornbills with the menu serondeng with glutinous rice or kelupis and Fathul Khair Mohd Dahlan who grew up in Selangor which was famous for its dish kuih koci.

In relation to that, through the short story Bihun Goreng Berkuah Laksa the highlighting of ibrah on family is observed when the image of a household is full with love resulting from the touch of a woman in cooking is expressed by the author. It was found that the character of Nordiana Humairah is the child of the couple Hamizah and Razali who has a very polite personality. The fried noodle rice with laksa gravy dish cooked by Hamizah during her lifetime has led to her daughter's memory and love for her as a highly respected and glorified woman. Although Hamizah has passed away, Hamizah's cooking, however, remains as a union of love with her daughter. The character of Nordiana Humairah that is developed clearly shows the ibrah on family revealed by the author in this short story as a lesson to the readers. In fact, Nordiana Humairah's respect and love for her father, Razali is eternal as the advice of the late Hamizah to her daughter. It turns out that the mother's cooking in preparing the fried noodle rice with laksa gravy dish is a lasting bond of love between a child in the family. Hence, it is clear that the Malay food culture and the preparation, although it is a bit complex, has become the source of strong and harmonious relationship in the family. Based on the food served, it can strengthen the sense of love and affection between children and the parents:

... Her eyes glazed over at Razali, who was in his early 50 s. Once

in a while, her eyes glanced at the clear white glass plate 
containing fried noodle rice with laksa gravy. There was only half of her favorite food left on the plate. Her appetite for the food never faded. That was her favorite food since childhood. She herself did not think how much fried noodle rice with laksa gravy was a favorite of her late mother, now inherited by her.

(Nordin, 2015: 3)

...Matanya merenung sayu ke muka Razali yang berusia awal 50-an itu. Sekali-sekala matanya menjeling ke arah pinggan kaca putih jernih yang berisi bihun goreng berkuah laksa itu. Tinggal separuh lagi makanan kegemarannya dalam pinggan itu. Seleranya pada makanan itu tidak pernah pudar. Itulah makanan kegemarannya sejak zaman kanak-kanak lagi. Dia sendiri tidak menyangka betapa bihun goreng berkuah laksa yang menjadi kegemaran arwah mamanya, kini dia pula yang mewarisinya.

(Nordin, 2015: 3)

Next, the ibrah on family in the short story Serondeng Nasi Pulut was highlighted when the main character deeply respects and loves his mother even though she has passed away. The love expressed in this short story were presented through the Malay food culture dish, namely serondeng with glutinous rice which has become a dish for generations in a family in the community of the Land of the Hornbills. Through the serondeng with glutinous rice dish also it presents the strong relationship in a family and is maintained so as not to be drowned across time. In fact, the serondeng with glutinous rice dish is not just a cuisine to remember the ancestors who have passed away but also a medium in linking religious knowledge in the relationship of a family. The author reveals about the role of a child who has a solid religious knowledge will remind and advise his mother who is less knowledgeable in Islamic law. This is clearly shown when a mother is given a religious enlightenment about the ritual of preparing the serondeng with glutinous rice dish is not merely an act of remembrance for family members who have passed away but also as a union of love in the family. This is because for someone who has passed away, only good deeds and prayers can be offered to them, and the dishes are actually merely a sign of remembrance and love for them. Although the preparation of kelupis is quite complex, a mother, however will make it work for the sake of the bonding and as sign of love in the family:

Mom is busy with her kelupis back and forth.The term kelupis in the Sarawak dialect is glutinous rice cooked with coconut milk. Half cooked, then wrapped in palm leaves. Then, it is steamed in a steamer to make sure it is properly cooked and lasts longer. The longest it will last is for a week. It will not get spoiled too fast.

(Jamilah, 2016: 42)

Mak sedang sibuk ulang-alik dengan kelupisnya. Istilah kelupis dalam loghat Sarawak ialah nasi pulut yang dimasak dengan air santan kelapa. Separuh masak, kemudian dibalut dengan daun 
palas. Kemudian, dikukus di dalam pengukus untuk memastikan ia betul-betul masak dan tahan lama. Paling lama pun bertahan selama seminggu. Tidak basi terlalu cepat.

(Jamilah, 2016: 42)

Apart from that, in the short story Kerana Kuih Koci ibrah on family was presented through a mother's love that has made a child love the variety of traditional cakes she makes. Although in the beginning his son did not like kuih koci because of the coconut filling which he considered as a small worm, but thanks to the preparation that is followed by a rather complex effort, his son changed his attitude. This short story shows the bond of love and warmth in a family as a result of the preparation of kuih koci made by a mother for her children. It is observed that kuih koci is a symbol of the unity of kinship among family members when gathered to enjoy afternoon tea. Author reveals the significance of traditional cakes specifically kuih koci among the Malay community as a very significant contribution to the younger generation's love towards Malay food culture so that it will not be drowned across time. In addition, this is able to strengthen the relationship between the young and the elder generation in a family in order to maintain the heritage of Malay food culture. Thus, it is clear that this short story conveys the ibrah on family in the Malay food culture as a lesson to the readers. This short story conveyed the message on ibrah regarding the importance of a harmonious relationships that is the backbone of the bonding in a family:

The aroma of kuih koci steamed with banana leaves aroused my appetite to touch it. When everything was done, our family gathered in the kitchen. Enjoying the tea time. Hot tea-O, pumpkin kuih koci and banana fritters. I ate a lot of kuih koci. No more shadows of small worms. Not only kuih koci, now I can eat all kinds of cakes with coconut filling and grated coconut.

(Fathul Khair, 2016: 8)

Haruman kuih koci yang dikukus bersama daun pisang membangkitkan seleraku untuk menjamahnya. Selesai segala urusan, kami sekeluarga berkumpul di dapur. Menikmati hidangan minum petang. Air teh-O panas, kuih koci labu dan pisang goreng. Banyak kuih koci yang aku makan. Tiada lagi bayangan ulat-ulat kecil. Bukan kuih koci sahaja, sekarang semua jenis kuih yang ada inti kelapa dan kelapa parut aku boleh makan.

(Fathul Khair, 2016: 8)

\section{Conclusion}

All in all, it can be said that the ibrah based on Malay food culture in the selected Malay short stories clearly shows some of the lessons that can be a very useful message to the readers. Through Malay cuisine in Malay food cultures, it has shown efforts of the author to reveal their own symbol in encouraging the readers to reflect on and contemplate about life. Ibrah about religion is clearly reflected in the short stories Bihun Goreng Berkuah Laksa, Serondeng Nasi Pulut dan Kerana Kuih Koci based on the characters and characteristics developed in the 
three short stories as lessons in enhancing religious knowledge to build personality and to solve daily problems.

Next, ibrah about family in all three short stories studied also encourages the readers to love the heritage of Malay food culture among family members, love between siblings as the result of mom's cooking and obeying all the orders of the parents. The short stories Bihun Goreng Berkuah Laksa, Serondeng Nasi Pulut and Kerana Kuih Koci have presented a lesson to the readers to place the family institution as the pinnacle of priority in realizing the struggles of life. It was found that the Malay dishes in the three short stories were able to make the heritage of Malay culture a very meaningful lesson in enhancing religion and family. Moreover, Bihun Goreng Berkuah Laksa, Serondeng Nasi Pulut and Kerana Kuih Koci were seen as a symbol of unity and love between man and man (habl min al-Nas) as well as the bond between a man with the Almighty Creator ( $h a b l$ min Allah).

\section{References}

The Qur'an and its translation. (2010). Shah Alam: Yayasan Restu Malaysia.

Ariff, M. (2018). Penggemar Karipap dan Momentum Hari Lahir. Mingguan Malaysia. Kuala Lumpur: Utusan Melayu Sdn. Bhd.

Amaruszati, N. R. (2018). Sesar Unjur Kampung Belawai. Mingguan Malaysia. Kuala Lumpur: Utusan Melayu Sdn. Bhd.

Azizi, H. A. (1983). Tulang Pekasam Ikan Puyu. Mingguan Malaysia. Kuala Lumpur: Utusan Melayu Sdn. Bhd.

Bushra, T. (2021). Di Sebalik 114 Nama-nama Surah. Puchong: Pacu Publishing.

Faisal, T. (2010). Ketupat Cinta. Kuala Lumpur: Aberdeen Sdn. Bhd.

Faisal, T. (2015). Cinta Gendang Kasturi. Mingguan Malaysia. Kuala Lumpur: Utusan Melayu Sdn. Bhd.

Fatimah, B. (1980). Nasinya Tumpah. Mingguan Malaysia. Kuala Lumpur: Utusan Melayu Sdn. Bhd.

Fida, R. (2016). Gulai Siput Daun Kaduk. Shah Alam: Karangkraf Sdn. Bhd.

Khair, F. M. D. (2016). Sfera Bersegi 5. Kuala Lumpur: Malaysian Institute of Translation \& Books.

Syahminan, H. Z. (1990). Jalur Kehidupan Manusia Menurut Al-Quran. Jakarta: Kalam Mulia Publisher.

Harun, Y. (2004). The Moral Values of the Qur'an. Kuala Lumpur: Al-Hidayah Publishers.

Jaffary, A. (2003). "Cultural Studies in the Context of Regional Da'wah" in. Dakwah In the Socio-Cultural Perspective of Malaysia-Indonesia, Bangi: Department of Dakwah \& Leadership Studies, Universiti Kebangsaan Malaysia.

Jamilah, E. (2016). Serondeng Nasi Pulut. Kuala Lumpur: Malaysian Institute of Translation \& Books

Hassan, L. (1991). Kreativiti dan Pendidikan-Suatu Kajian Psikologi dan Falsafah. Kuala Lumpur: Dewan Bahasa dan Pustaka.

Hasan, L. (2002). A Psycho-Pedagogical Approach to Islamization of Knowledge. Gombak: International Islamic University Malaysia Press.

Kamariah, K. (2016). "Malay Food Culture in Selected Short stories" in. Proceedings of the International Seminar of Archaeology, History, Culture and Languages in the Malay Archipelago (ASBAM) 5th in Makassar on 26-27 July 2016. 
Kamariah, K., \& Pabiyah, H. (2021). "Air Tangan Ibu" in Malay Culinary Culture And from an Islamic Perspective as Represented in Selected Malay Novels. Malay Literature Volume 34 Number 1 June 2021. Kuala Lumpur: Dewan Bahasa dan Pustaka, p. 103-118.

Chih, L. K. (2011). Jeruk Maman Emak. Berita Minggu. Kuala Lumpur: The New Straits Times Sdn. Bhd.

Lulu, M., Udin, S., Iman, M. F. (2017). "Effectiveness of Mau'izah Ibrah Method in Learning Model in Student Team Achievement Divisions towards Student Learning Achievement in the Subject of Akidah Akhlak in MTS Plus Darulhufaz Jatinangor" in.Tarbawy, Indonesian Journal of Islamic Education, 4 (2).

Malim, G. P. K. (2013). Gulai Tempoyak Ikan Sebarau. Dewan Sastera. Kuala Lumpur: Dewan Bahasa dan Pustaka.

Nisah, H. (2009). Lemang Nan Sebatang. Berita Minggu. Kuala Lumpur: The New Straits Times Sdn. Bhd.

Nordin, S. (2015). Bihun Goreng Berkuah Laksa. Kuala Lumpur: Malaysian Institute of Translation \& Books

Shahkang. (2018). Gulai Pulut Serunding Buat Nazihah. Mingguan Malaysia. Kuala Lumpur: Utusan Melayu Sdn. Bhd.

Shahkang. (2018). Setalam Halwa Maskat. Mingguan Malaysia. Kuala Lumpur: Utusan Melayu Sdn. Bhd.

Shuhaibun, Y. (2002). Ambuyat. Dewan Sastera. Kuala Lumpur: Dewan Bahasa dan Pustaka.

Irving, T. B. (1980). The Qur'an Selections from the Noble Reading. Singapore: Omar Brothers Publictions Pte Ltd.

Maimunah, U. M. T., \& Zulkarnain, M. (2020). Watak dan Perwatakan dalam Sastera-Islam, Barat, Melayu. Serdang: Universiti Putra Malaysia. 